\title{
Civil liability of doctors and the employment relationship
}

\author{
Piotr Stępniak
}

Department of Medical Law, Faculty of Health Sciences, Poznan University of Medical Sciences, Poland

\begin{abstract}
Article takes the issue of liability of doctors in connection with the provision of health services. The author suggests that this responsibility depends on the type of their employment by the therapeutic entity. So it is regulated by civil law and labor law. Therapeutic entity is as responsible as a company, ie. on the basis of risk. Responsibility of the doctor depends on whether he is employed on the basis of a civil contract, or contract of employment. The author widely discusses implications of different employment contracts. He indicates that the best situation the doctor has as an employee within the meaning of the Labor Code. His liability is in this case reduced to a minimum, i.e. up to 3 - monthly salaries. In the case of civil law contracts, the liability is unlimited. Therefore, the author recommends in the conclusions, that doctors should make contracts of liability insurance.
\end{abstract}

Keywords: doctor; hospital; employment relationship; patient; damage; liability.

The article is devoted to the civil liability that doctors bear due to provision of health services. This liability is placed primarily in the area of civil law, some of its aspects are also regulated by labor law. Due to the fact that it involves the civil liability of health care entities that employ doctors, especially hospitals, I also pay some attention to this issue at the outset.

The issue of the civil liability of health care entities is systematically gaining importance. This is a result of system and economic changes in the current economic and social reality. Thus, it is worth to briefly indicate the most important issues.

The principles of the civil liability are varied and they depend on its addressee. They are another basis for the responsibility of the hospital, another for a doctor and wider medical staff.

The responsibility of the hospital is associated with the functional aspect of its activities, while the liability of doctor is, among other, related to the employment relationship which connects him with the hospital.

Analyzing the legal aspects of the functioning of hospitals, in consequence of which may arise all sorts of damage, it is necessary to pay attention to the reg- ulations governing enterprise's liability'. It is worth remembering that, at present, under the Act of 15 April 2011 on medical treatment ${ }^{2}$, the hospital is treated just as an enterprise. According to art. 2 paragraph 1 point 9 of this Act - "the hospital is an enterprise of health care entity in which this entity carries out medical treatment such as hospital services". In point 8 of that paragraph, the enterprise is defined as a set of assets, through which the health care entity performs a specific type of medical activity ${ }^{3}$.

The basic regulation in defining the civil liability of the hospital as an enterprise is art. 435 of the Civil

\footnotetext{
This issue was discussed in detail, i.a., in the following comments to the Civil Code: E. Gniewek (ed.) Kodeks cywilny. Komentarz, Wydawnictwo C.H. Beck, Warszawa 2008; Z. Radwański, A. Olejniczak, Zobowiązania - Część ogólna, Wydawnictwo C.H. Beck, Warszawa 2008.

2 Dz. U. 2011 Nr 112 poz. 654.

${ }^{3}$ Slightly different an enterprise is defined by art. 55 of the Civil Code. It provides that an enterprise is an organized set of tangible and intangible elements intended for conducting business activity. As shown, the difference consists in taking into account the intangible components and to indicate the goal of economic activity.
} 
Code. This article regulates the liability for damages on the basis of the principle of risk ${ }^{4}$. This is a risk associated with the movement of the enterprise based on forces of nature and as a result of this risk damage may arise. According to the norm contained in it, the liability for damages is borne by the person who runs the enterprise.

At present hospital is classified as an enterprise moved by forces of nature as well ${ }^{5}$. This justifies a conclusion that its civil liability towards patients and third person is formed like liability of a enterprise. Therefore, it is responsible for all the events, as a result of which the damage associated with its movement may arise. It includes a responsibility for damage occurring during and in connection with the provision of health services by medical staff, especially doctors. In addition, random events which can't be predicted. For example, when a patient broke his hand, going to the toilet in the corridor. So, this type of responsibility extends very far. In the certain inevitability of such events, it's very difficult to avoid it.

Taking this fact into consideration, the legislature gave hospital various possibilities of defense against this type of liability for damages. Its basic principles are defined by the article indicated above - 435 of the Civil Code. This article allows for the exclusion of liability for damage caused by the movement of the hospital, if the damage is caused by force majeure, or solely by the fault of the victim or solely by the fault of a third party, for which hospital is not responsible. However, a conditions is to prove that one of the abovementioned situation has occurred. It must be proved by the hospital, because it involves certain legal consequences for the hospital. More specifically, the abolition of civil liability (cf. Art. 232 of the Code of Civil Procedure). However, this is not facile. An observation of judicial practice shows that proving of occurrence of one of evidence mentioned above which causes the exclusion of liability for damages in civil proceedings, often fails. Unless, it includes obvious cases. For example, a patient's inattention who enters the slippery floor in spite of the warning and consequently falls over. Or, the provision of stale foods to the hospital, consumption of which causes poisoning.

\footnotetext{
4 Widely about this principle i.a.: A. Śmieja, Odpowiedzialność za szkody wyrządzone przez ruch przedsiębiorstwa (art. 435 k.c.), Prace naukowe Uniwersytetu Ekonomicznego we Wrocławiu Research Papers of Wrocław University of Economics, nr 372 • 2014.

5 Cf. art. 2 ust. 1 pkt 9 Ustawy z dnia z dnia 15 kwietnia 2011 r. o działalności leczniczej.
}

The paradox lies in the fact that in such cases the compensation disputes generally do not occur.

It should agree with $\mathrm{M}$. Nesterowicz that the damage in hospitals may concern two aspects of their functioning, i.e. "organizational fault" and the doctors' actions of and other medical staff $f^{6}$.

Analyzing a little more closely this second aspect, it should be noted that, at present, among others, a type of employment relationship, which connects doctors to hospital decides about the civil liability of doctors. Currently, the most common is fact that doctors are employed in public hospitals on the basis of the so-called "contracts" ("kontrakt" in Polish), which are agreements of civil law and employment contracts. In the non-public hospitals, or clinics and private clinics doctors are employed also on the basis of contracts, or beyond them on the basis of contract of mandate or contract involving performance of medical services which is a variation of the previously mentioned contracts.

The importance of the type of employment for liability has clearly increased ${ }^{7}$. So, it is necessary to devote a little more attention to this issue. All the more that, due to the transformation of property relations, the responsibility of doctors from public hospitals is only a narrow fragment of their total liability.

In the past decades, the contract of employment was a common, widely used in practice basis of the employment relationship. A feature that distinguishes this agreement from the so-called civil contracts (contract, contract involving performance) is the specific subject of this contract. In fact, it is work performed personally, under the conditions of subordination, in a place designated by an employer, as well as at his risk $^{8}$.

A further reasoning in this regard, because of greater transparency, should be based upon the analysis of an example of the specific case of damage.

A claimant J. N. on September 19, 2008 had an accident on the way to work. As a result, he suffered a right knee meniscus injury. On October 12, the same year, in a public center of orthopedics, a surgical intervention was performed. After surgery, the claimant was discharged from the hospital with the recommendation of walking with elbow crutches. His disability to work

\footnotetext{
6 M. Nestorowicz, Prawo medyczne, Toruń 2007, p. 334.

7 Widely about this i.a.: P. Stępniak, Prawne aspekty odpowiedzialności cywilnej zakładu opieki zdrowotnej oraz jego personelu (in:) Sprawne zarządzanie zakładem opieki zdrowotnej (eds.) M. Głowacka, J, Galicki, Poznań 2010.

8 Cf. Judgment of SN of 18 June 1998, I PKN 191/98, OSP 1999, nr 10, poz. 184; also: Kodeks pracy. Komentarz (ed.) B. Wagner, Gdańsk 2004, p. 35.
} 
was determined until December 3, 2008. However, after this date, the claimant has continued to stay on medical sick leave. As a consequence, he was dismissed on April 26, 2009.

On June 22, 2009 he was admitted again to the center of orthopedics, where arthroscopic surgery and removal of loose body was performed. Three months later, he was examined by magnetic resonance imaging. This examination found an increased signal intensity spot of lateral meniscus, scattered posterior horn of the medial meniscus and a slightly increased amount of synovial fluid around the medial femoral condyle. Relying on the results of this examination, the claimant charged three doctors who had performed a surgical operation with a commission of medical error.

The first issue that must be resolved in this case, is a proper definition of the defendant. It is necessary to indicate how the employment relationship connects doctors with the hospital where the surgery was performed. Because, the claimant sued doctors for damages. So, the doctors were employed under a contract of employment. This resulted, on the side of doctors, in the lack of passive capacity to be a party. This capacity allows to be sued in the proceeding ${ }^{9}$. Doctors who didn't have this capacity, they couldn't be the defendants.

If so, it had to properly identify who can be sued. In this regard, the content of the two articles is helpful, i.e. Art. 430 of the Civil Code and $120 \S 1$ of the Labour Code.

It is worth quoting articles mentioned above. Article 430 of the Civil Code states the following:

who, on his own account, entrusts the performance of action to a person who, while performing the action, is subjected to his management and is obliged to follow his instructions, is liable for damage caused by a fault of the person during the performing of the entrusted action.

This regulation governs the rules of liability of a superior for a subordinate. Based on the interpretation of its content it must be assumed that the doctors were subordinate to the subject entrusting them to perform operations.

Therefore, follows from the wording of mentioned regulation, a material premise of liability for damage is the relation of management and subordination

\footnotetext{
9 Art. 65 and art. 194-196 of Act of 17 November 1946 Kodeks postępowania cywilnego, Dz. U. nr 43, poz. 296 z późn. zm.
}

between a person entrusting the execution of activities and a person entrusted with the activity. From this perspective, a supervisor is a person who, on his own account, entrusts the performance of an action to a person who, while performing the action is subjected to his management and is obliged to follow his instructions. Whereas the subordinate is a person under this management and having the duty to obey the supervisor's instructions. The subordinate performs entrusted activity "on own account" of the supervisor.

An interpretation of Art. 430 of the Civil Code, leads to the conclusion that it is particularly important, for the relation of supervisor - subordinate, that the first isn't independent in the performance of a given activity. The concept of subordination can be understood broadly and narrowly. In the first case, this is the subordination of the general organization. In the second, this is just a subordination to the supervisor's instructions, formulated in the performance of the activity.

Consequently, a determination who is doctors' supervisor may raise some doubts. In fact, that can be two subjects or, as someone prefers - two people. Physical person or legal person. The first of these would be the hierarchical superior of defendants orthopedists. The second - the hospital employing them.

In civil law doctrine and jurisdiction of common court of law, the second of these approaches is particularly prevalent. Thus, it is assumed that the doctor's supervisor is not his hierarchical supervisor, indicated in the organizational structure of the hospital (e.g. chief surgeon), but the hospital itself as an institution that is a legal person ${ }^{10}$.

However, a liability of hospital for acts of professionals, such as doctors, may raise doubts. In fact, they are entitled to a wide range of autonomy in making decisions ${ }^{11}$. This liability is formed not only by an existence of headship but also by the type of employment relationship, which connects them with the hospital. As a result, although hospital will be responsible for the damage caused to the patient by a doctor, as his supervisor, the ranges of this responsibility are highly diversified.

A general and necessary condition for its responsibility is that the damage was the consequence of the performance of health services entrusted to the doctor, and doctors as subordinates of hospital bear the

\footnotetext{
${ }^{10}$ The hospital is represented by its authority defined in the statute, i.e. most frequently by the Director. Cf. art. 38 of the Civil Code.

${ }^{11}$ Commentary to the Civil Code, ed. G. Bieńka, Warszawa 2005, p. 365.
} 
fault for this damage. In other words, a responsibility of the direct perpetrator i.e. doctors, must occur ${ }^{12}$. This includes, in some simplification, a situation when a doctor performs medical services, for example surgery, in a faulty manner. It results mostly from a medical malpractice. It can be caused by various reasons, e.g. carelessness or negligence in diagnosing, performing treatments, using of inappropriate drugs, etc.

For the adoption of doctors guilt, it is not needed to prove that he violated the rules on the safety of life and human health. On the contrary, according to the opinion expressed by the Supreme Court (Sąd Najwyższy), it is sufficient that he desisted the principles of carefulness and safety arising from life experience and circumstances of the accident ${ }^{13}$. It is worth noting that while the premise for the hospital as a supervisor doctor is always subordinate fault, it is not required any superior fault.

Another premise of liability of health care institution as a doctor superior is to establish, if damage occurred during the action, not during opportunity of execution. The requirement of causing damage in the delegated act means that "between entrusting activities and action, which resulted in damage occurred, there should be a causal link".

Considering the nature of this relationship it should be mentioned about the article 361 \& 1 of the Civil Code, according to which person required to compensation is liable only for the normal consequences of an act or abandonment from which the damage occurred. The normal consequences of action in the interpretation of this provision are the ones that - based on the life experience - can be considered as the effects of type of action or abandonment, in contrast to accidents, which extend beyond this rule ${ }^{14}$.

It should be emphasized, that in the case law the Supreme Court consistently adopts the principle of the article 430 of the Civil Code, only if matter of damage is caused during delegated act, but not if the damage is caused during opportunity of execution. The criterion for distinction between this two situations is the aim of the perpetrator or the causation between the damage caused and the delegated activity.

If it is possible to state the guilt of the doctor, and the doctor is not employed under a contract of employ-

\footnotetext{
${ }^{12}$ It also relates to a nurse, a medical analytics and other category of medical staff.

13 Judgement of the Supreme Court, April 9, 1975, case number: II CR 140/75 (unreleased).

${ }^{14}$ Judgement of the Supreme Court, December 9, 1958, case number I CR 867/58, OSPiKA 1960, poz. 292.
}

ment, the hospital and the doctor are jointly and severally liable for damage. For a doctor the responsibility is very far-reaching, because he responses with all his property.

There are exceptions from the principle of joint and several liability, referred in article 430 of the Civil Code. Legal structure of this exceptions is based on differences in the type of employment relationship between the doctor and the hospital. The best situation for the doctor is when he signed contract of employment, because he is in fact an employee within the meaning of the Code.

In favor of the doctor liability, labor laws are corrected radically. They are included in the basic act ie. Labor Code, which regulates the issues of employment, including medical staff.

It should be recalled that the definition of employee in labor law is constraining. According to art. 2 of the Labor Code an employee is a person employed under an employment contract, appointment, nomination or a cooperative contract of employment. Only employee benefit protection from civil liability provided in this Code. So, even though the work can be perform on the other basics than contract of employment, e.g.: on specific task contract, contract of mandate and agency agreement, the person that takes it will not use the protective elements from labor laws ${ }^{15}$. This also includes protection against liability.

Rules which protect doctors from liability are regulated in several law of the Labor Code. They are gathered in the Department Fifth in Chapter I. The first, that should be mentioned, is article 115. According to it, the employee is liable for damage within the limits of the actual loss incurred by the employer and only for the normal consequences of acts or abandonment from which damage resulted. This rule of law is very important, because at the same time it determines the scope of civil liability of the employer, i.e. health care entity and therefore the hospital.

However, the most important issue for establishing the rule of civil liability for orthopedic doctors who operate J.N. is art. $120 \S 1$ of the Labor Code.

According to this article, in the event of causing harm to a third party by the employee in the performance of his duties, only the employer is obligated to compensate damage. Commenting on the importance of the rule of liability of the hospital and its employees it should be referenced to The Resolution of 7 judges

\footnotetext{
$\overline{15}$ Labor Code, Comment ed. B. Wagner, Gdańsk 2004. p. 15
} 
of the Supreme Court, June 12, 1976, case number III CZP on $5 / 76^{16}$. It provides as follows:

art. 120 \& 1 of the Labor Code is a breakthrough from the rules adopted in the Civil Code in connection with receiving a third party in bringing substantive in relation to the perpetrator, because to repair the damage in such a system is required only workplace.

It should be emphasized that this provision applies to the hospital, regardless of whether it is public or not, the cooperative medical clinics and even private clinic. This means that in every case when a doctor is employed under a contract of employment for any committed by him mistakes and offenses, in particular for errors in medical malpractice, is responsible - and exclusively responsible- an institutional therapeutic entity that employs him.

The provision of article. $120 \& 1$ of the Labor Code is repealed, therefore, liability of doctor or other medical staff as employees to the injured patient. In other words, it deprives them locus standi, referred to in the cited resolution. If so, operating plaintiff doctors were not employed in orthopedics center under a contract of work, they would have such legitimacy. This means that they could be sued and be liable for the damage caused to him jointly and severally with the hospital, where they were operating.

The defendant doctors, however, were originally employed in the hospital under a contract of employment. So they used from the benefits of protection from civil liability provided in the article $120 \S 1$ of the Labor Code. It is always entitled to employees, regardless of whether a hospital is public or private.

Summing up all the comments that have been done so far, one request can be formulated that the doctor employed under a contract of employment is in a comfortable situation. His liability for defective treatment, negligence, etc. is in fact very seriously reduced. The hospital has indeed so recourse to the doctor, but the claims may be taken only when the hospital repaired the damage caused to the patient. Usually by paying him appropriate compensation, established either by agreement with him, or during court proceedings.

Regardless of the amount of compensation, construction of recourse to the doctor in the provisions of the Labor Code allows the hospital to call a doctor to return only a portion of its parts. It cannot exceed 3 - monthly salary (cf. article 119 of the Labor Code).

\footnotetext{
${ }^{16}$ OSNCP 1977, nr 4, poz. 61.
}

So if hospital decides to investigate claims of recourse, it may with the consent of the employee deduct the amount of recourse from salary up to the amount of free classes in accordance with the provisions of the execution to the extent specified in the provisions of the Labor Code ${ }^{17}$. It is worth recalling that the amount of compensation is determined with salary at the time of injury ${ }^{18}$ and calculated in accordance with $\S 3$ of the Regulation of the Minister of Labor and Social Policy, May 29, 1996 on the method of determining the remuneration for the period of inactivity, and the remuneration constituting the basis for calculating the compensation, severance pay, compensatory allowances to salaries and other charges provided for in the Labor Code $^{19}$

Payment of the amount of recourse in the manner indicated above allows to avoid high court costs. It also avoids the costs of enforcement proceedings initiated by the bailiff on the judgment of the court. In the absence of consent by the doctor, however, the hospital would have to take court proceedings.

It should be noted that the regression is the law of the hospital. So it may use it or not. If the hospital did not occur to the doctor with recourse claim, but does not have to do this, the doctor is not liable at all. An exception to this rule comes only when a doctor would do harm intentionally. Experience shows, however, that such situations are extremely rare. Another situation is when the hospital is insolvent or has been incorrectly insured, and finally, when the damage was caused not by performing medical services, but on the occasion of their execution (i.e. perform various duties of the employee).

To sum up, the patient, in our case the plaintiff, who had defective knee surgery can enforce his claims only from the center of orthopedics. The doctors who operated him, working on a contract of employment, are subject to the compensation regime specified in the labor code, but not much further-reaching rules of the Civil Code.

The last mentioned rules would apply in the case of employment doctors on the basis of a contract or a contract of mandate. So let's talk a bit more about this issue.

The legal situation in the employment of doctors and other medical personnel on the basis of a contracts is completely different. This contract is in fact

\footnotetext{
${ }^{17}$ Cf. art. 832 of Labor Code.

${ }^{18} \mathrm{Cf}$. The Resolution of 7 judges of the Supreme Court, case number: V PZP 4/75, OSNCP 1976, z. 1 . poz. 2.

${ }^{19}$ Dz. U. Nr 62, poz. 289.
} 
a civil law agreement. Its essence is defined in art. 734 $\S 1$ and $735 \S 1$ of the Civil Code. It is worth to cite their content.

Art. $734 \S 1$ - Person who accepts contract of mandate for work commits to provide a specific legal act for the principal

and

art. $735 \S 1$. If neither the contract nor the circumstances do not suggest that person who accepted the order committed to do it without pay, for the execution of the order should be paid.

As it can be seen, the contract of mandate is in many ways similar to the contract of employment. Nevertheless, there are several differences between them which are of a fundamental nature. The two most important differences based on the fact that the contractor does not perform the work under the direction of the principal, so the health care facility, but entirely on their own account, moreover, he does not need to work in a place designated by the client.

With these two differences, for existence and for the principles of civil liability for a doctor more important is first. If he does not provide medical services under the direction of a superior designated by the client, the latter is responsible for the damage together with the doctor by the principle of solidarity. This means that the patient can sue for damages both institutional therapeutic entity and a particular person providing health services, which directly caused the damage.

It is worth noting that for the doctor this situation is incomparably less favorable. In the case of employment on a contract of employment he is by law excluded from participation in the process (Labor Code). Quite different is his process situation in the case of employment on contract of mandate. The provisions of the Civil Code which regulate this situation, do not provide any limitations of it. As a result, the doctor must participate in the process, in solidarity with the health care facility that hired him. Solidarity in this case means, however, that the injured patient has the right to sue the doctor only. Patient may do it particularly in the case when therapeutic entity becomes, e.g. insolvent. In this case also, even if the judgment order to pay for damages jointly and severally from the hospital and doctor, the doctor is required to pay total compensation.
The same situation is in the case of employment on the basis of the so-called. contract. In either case, the doctor liability is essentially unlimited.

Ending this short presentation of the problems associated with the liability of doctors for any damage caused to patients during and in relation to medical services, it is worth asking a few conclusions.

1. Present labor market and health services are very flexible. They are a subject to the sharp rules of the economic game. This situation has its advantages and disadvantages. They are shown in today's legal regulations. It is worth to know them.

2. Legal regulations are very flexible, what allows people to customize various legal structures, in particular the various contracts to perform medical services adopted to the needs of employers doctors, as well as themselves. We must also remember that the various contracts not only provide varied benefits, but involve various risks. One of the most important risks is to reduce or increase the scope of liability of doctors for all sorts of errors and shortcomings, especially for malpractice. In this article I tried to show that risk, as well as consider how it can be reduced to a minimum. The greatest opportunities in this area gives the contract of employment. The problem is that not always the employer and the doctor want it to contain.

3. The most important, practical conclusion that follows from the article, is recommendation to insure against civil liability in connection with the medical profession. Especially against responsibility for medical malpractice.

4. The rules and scope of insurance must be determined in order to optimally protect doctor from medical liability in situations where malfunctioning would cause a patient harm ${ }^{20}$.

\section{Acknowledgements}

\section{Conflict of interest statement}

The authors declare no conflict of interest.

\section{Funding sources}

There are no sources of funding to declare.

\section{References}

1. Gniewek E. (ed.) Kodeks cywilny. Komentarz, Wydawnictwo C.H. Beck, Warszawa 2008.

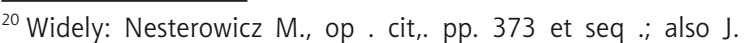
Jończyk, Naprawienie szkody (krzywdy) pacjenta w związku z ubezpieczeniem zdrowotnym, Praca Socjalna, nr 9/2003.
} 
2. Jończyk J. Naprawienie szkody (krzywdy) pacjenta w związku z ubezpieczeniem zdrowotnym. Praca Socjalna. 2003/9.

3. Kodeks pracy. Komentarz. Wagner B. (ed.). Gdańsk 2004; 15. Komentarz do kodeksu cywilnego. Bieńka G. (ed.). Warszawa 2005; 365.

4. Nestorowicz M. Prawo medyczne. Toruń 2007.

5. Radwański Z, Olejniczak A. Zobowiązania - Część ogólna. Wydawnictwo C.H. Beck, Warszawa 2008.

6. Stępniak P. Prawne aspekty odpowiedzialności cywilnej zakładu opieki zdrowotnej oraz jego personelu. In: Głowacka M, Galicki J. (eds.). Sprawne zarządzanie zakładem opieki zdrowotnej. Poznań 2010.

7. Śmieja A. Odpowiedzialność za szkody wyrządzone przez ruch przedsiębiorstwa (art. 435 k.c.). Research Papers of Wrocław University of Economics. 2014;372.

Also:

1. Ustawa z dnia 15 kwietnia. 2011 r. o działalności leczniczej, Dz. U. 2011 Nr 112 poz. 654.
2. Uchwała 7 sędziów Sądu Najwyższego w sprawie V PZP 4/75, OSNCP 1976, z. 1 . poz. 2.

3. Wyrok SN z 18 czerwca. 1998, I PKN 191/98, OSP 1999, nr 10, poz. 184.

Acceptance for editing: 2016-03-15 Acceptance for publication: 2016-03-31

\section{Correspondence address:} Piotr Stępniak

Department of Medical Law, Faculty of Health Sciences Poznan University of Medical Sciences, Poland e-mail: pstepniak@ump.edu.p 